\title{
Thermal Properties of some Legume Seeds
}

Matouk, A. M. ${ }^{1}$; M. M. EL-Kholy ${ }^{2}$; A. Tharwat ${ }^{1}$ and Summer F. Shamala ${ }^{1}$

${ }^{1}$ Agric. Eng., Dept. Fac. of Agric. Mansoura Univ., Egypt.

${ }^{2}$ Food Process Engineering - Agriculture Engineering Res. Institute.

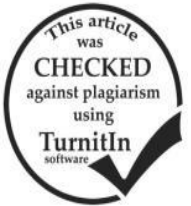

\section{ABSTRACT}

Specific heat, thermal conductivity and thermal diffusivity of three various varieties of faba bean (Giza 716, Giza 843 and Giza 3 mohsen) and three different varieties of lentil (Sina 1, Giza 9 and Giza 370) were determined as a function of moisture content and temperature. The specific heat and thermal conductivity were measured using the methods of mixture and transient state heat transfer. The experiments of work were done at five levels of seeds moisture content $\%$ (w. b.) and five temperature levels [40, 50, 60, 70 and $80^{\circ} \mathrm{C}$ ] with 3 repetitions. The thermal diffusivity was calculated from measured specific heat, thermal conductivity and bulk density. Specific heat of faba bean seeds varieties (Giza 716), (Giza 843) and (Giza 3 mohsen) and lentil seeds varieties (Sina 1, Giza 9 and Giza 370) were increased with the increase of moisture content and decreased with the increase of temperature. The thermal conductivity and thermal diffusivity of faba bean seeds increased with the increase of temperature and also with the increase of moisture content. The volumetric heat transfer coefficient was increased as the mass air flow rate and air temperature increased. Regression equations that could be used to express the relationship between thermal properties, moisture content and temperature were also presented.

Keywords: Thermal properties, Faba bean \& lentil seeds, Specific heat, Thermal conductivity, Thermal diffusivity, heat transfer coefficient.

\section{INTRODUCTION}

Legumes are consumed as a high source of protein, mainly in the Middle East, replaced the expensive animal proteins, (Gharibzahedi, et al., 2013).

Faba bean (Vicia faba L.) is a major leguminous crop that grown in Egypt; it is an essential source of protein for human and animal consumption, (Abdellatif, et al., 2012).

lentil (Lens culinaris Medik.) is an important traditional diet in developing countries like Egypt. Lentils are an excellent source of vitamins, energy, proteins, mineral elements, and carbohydrates, (Gharibzahedi, et al., 2014). The main dimensions, density and bulk density and volume as some of physical and thermal properties is important in design machines and equipment can used in harvesting, post harvesting and processing fields.

Many studies considered that temperatures and moisture contents is the most thermal properties effect on biological materials, Aviara, et al., (2008) for guna seed; Jangi, et al., (2011) for barley grains and Azadbakht, et al., (2013) for soybean Pod. Moisture content in cereal products has an imperative effect on the specific heat due to heat of absorption and specific heat of water (Tang, et al., 1991). The linear relation is the best fit curve to describe specific heat expressed moisture content, (Mohsenin, 1980).

Temperature has an important effect on the organic material specific heat although this has been generally ignored in the early work with grains, (Tang, et al., 1991).

The objective of this research work was to determine thermal properties of some varieties of faba bean and lentil seeds as a function of moisture content and temperature. The tested properties included thermal conductivity, specific heat and thermal diffusivity.

\section{MATERIALS AND METHODS}

\section{Sample Preparation}

The seeds of faba bean and lentil used in this study were obtained from the Agricultural Research Center (ARC), to grantee the purity of the selected varieties. The seeds were cleaned and sorted so that foreign matter, broken and immature seeds were removed. The initial moisture content was determined by drying the faba bean seeds samples in an electric oven at $\left(103^{\circ} \mathrm{C} \pm 1\right)$ for $72 \mathrm{~h}$. and lentil seeds at $\left(105^{\circ} \mathrm{C}\right)$ for $24 \mathrm{~h}$ which described by (ASAE, 2000c) and (ASAE, 1987) and then kept in a desecrator at the room temperature.

To achieve the favorite moisture levels for the studied, samples a calculated amount of water was added to the moisture conditioning unit using the following equation (Balasubramanian, 2001).

$$
\mathbf{Q}=\frac{\mathbf{W i}(\mathbf{M f}-\mathbf{M i})}{100-\mathbf{M f}}
$$

Where: $Q$ is the mass of water to be added in $\mathrm{kg} ; \mathrm{W}_{\mathrm{i}}$ is the initial mass of the sample in $\mathrm{kg}$; $\mathrm{M}_{\mathrm{i}}$ is the initial moisture content of the sample \% (w. b.), and $M_{\mathrm{f}}$ is the final moisture content $\%$ (w. b.).

Bulk density $\left(\rho_{b}\right)$ :

The bulk density $(\rho)$ of faba bean and lentil seeds varieties were determined by filling a container with sample from a height of $150 \mathrm{~mm}$ at a constant rate and weighing the contents. The volume of the container was estimated by filling the container with water and measuring it with $80 \mathrm{ml}$ measuring cylinder as recommended by (Matouk, et. al., 2004 b). The bulk density was determined as the ratio between the mass of sample and its total volume.

Bulk density was calculated as shown in equation

Bulk density $=\mathrm{W} / \mathrm{V}_{\mathrm{b}}$

Where: $\mathrm{W}=$ Weight of seeds bulk, $\mathrm{kg}$., $V_{b}=$ Volume of seeds bulk, $\mathbf{m}^{3}$.

Specific Heat (Cp):

The specific heat of samples was determined using a copper calorimeter placed inside a flask in the method of mixtures as described by Ogunjimi, et al., (2002) and Matouk, et al., (2006c). A sample of known weight and temperature was poured into the calorimeter containing water of known weight and temperature. The mixture was stirred with a copper stirrer until the equilibrium condition was attained. The final temperature was noted and the specific heat of the sample crops was calculated using the following equation.

$$
\text { CPg }=\frac{(W w+W e q)(t w g-t w) \times S P w}{W g(t g-t w g)}
$$

Where: Weq is the water equivalent $(\mathrm{Kg}), \mathrm{Wg}$ is the sample of mass $(\mathrm{Kg}), \mathrm{W}_{\mathrm{w}}$ is the mass of water $(\mathrm{Kg}), \mathbf{C p g}$ is the specific heat

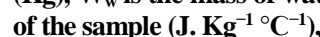

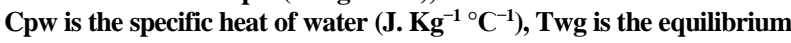
Temperature $\left({ }^{\circ} \mathrm{C}\right), \mathrm{Tg}$ is the initial temperature of the sample $\left({ }^{\circ} \mathrm{C}\right)$ and $\mathrm{Tw}$ is the initial temperature of Water $\left({ }^{\circ} \mathrm{C}\right)$. 


\section{Thermal Conductivity (K):}

A thermal conductivity meter with heating probe which was used to determine the thermal conductivity of the seeds bulk (k), fig. (1). The thermal conductivity of the studied crops was determined using a line heat source method as the most commonly used transient-state heat transfer method. For an infinitely long line heater in an infinite, homogeneous, and isotropic medium the temperature rises at a radial distance (r) from the line, heat source can be represented by the following equation:

$$
k=\frac{Q}{4 \pi \Delta T} \ln \frac{t 2}{t 1}
$$

According to (Matouk, et al., 2006a)

\section{Where:}
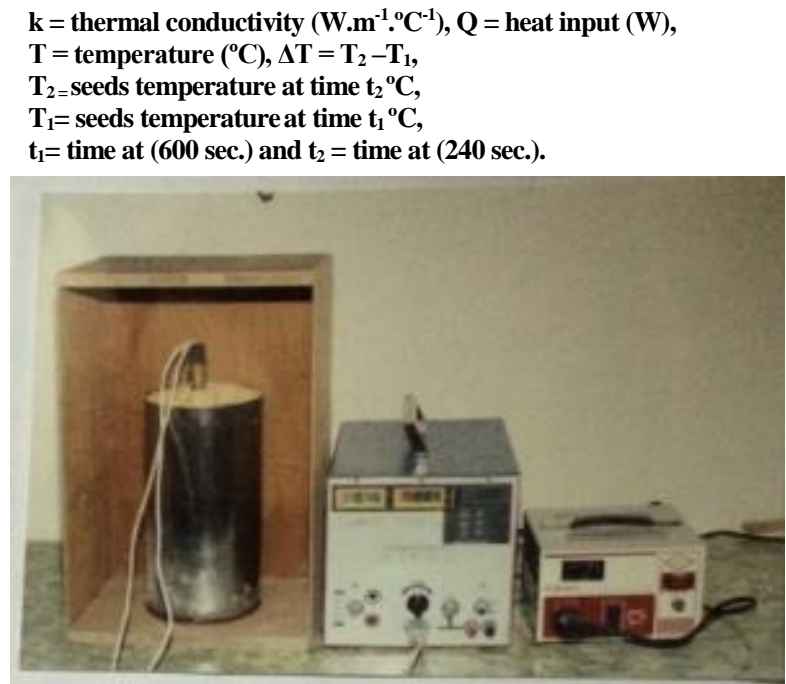

Fig. 1. Apparatus used for measuring the seeds thermal conductivity.

\section{Thermal Diffusivity $(\alpha)$ :}

Thermal diffusivity $(\alpha)$ was calculated based on the measured values of specific heat and thermal conductivity, the following relationship was applied.

$$
\propto=\frac{\mathbf{k}}{\text { p.cp }}
$$

According to (Mohsenin, 1980).

Where: $\alpha=$ thermal diffusivity $\left(\mathrm{m}^{2} \cdot \mathrm{s}^{-1}\right), \rho=$ bulk density $\left(\mathrm{kg} \cdot \mathrm{m}^{-3}\right)$, $\mathrm{k}=$ thermal conductivity $\left(\mathrm{W} \cdot \mathrm{m}^{-1}{ }^{\mathrm{o}} \mathrm{C}^{-1}\right)$, and $\mathrm{cp}=$ specific heat $\left(\mathrm{kJ} \cdot \mathrm{kg}^{-1} \cdot{ }^{\circ} \mathrm{C}^{-1}\right)$.

\section{Volumetric Heat Transfer Coefficient:}

In this study, seeds of faba beans and lentil varieties were dried to the equilibrium state at different air temperatures ranging from 40 to $80{ }^{\circ} \mathrm{C}$ and the values of heat transfer coefficient were measured at different air velocities ranging from 1 to $2.5 \mathrm{~m} / \mathrm{sec}$. using a forced air dryer in order to get the reconditioned samples to determine the volumetric heat transfer coefficient according to (Matouk, et al., 2001).

The volumetric heat transfer coefficient was determined using the following equation:

$$
\mathbf{h}_{\mathrm{cv}}=-\left(\frac{\mathrm{C}_{\mathrm{pg}} \times \boldsymbol{\rho}}{\mathrm{t}}\right) \ln \frac{\mathrm{T}_{\mathrm{a}}-\mathrm{T}_{\mathrm{g}}}{\mathrm{T}_{\mathrm{a}}-\mathrm{T}_{\mathrm{gi}}}
$$

According to (Matouk, et al., 2006 b)

Where: hcv $=$ volumetric heat transfer coefficient, $\mathrm{W} \cdot \mathrm{m}^{-3} \cdot{ }^{0} \mathrm{k}^{-1}$, $\mathrm{Cpg}=$ specific heat of seeds, $\mathrm{kJ} \cdot \mathrm{kg}^{-1} \cdot{ }^{-1} \mathrm{k}^{-1} \cdot \rho=$ bulk density, $\mathrm{kg} \cdot \mathrm{m}^{-3}$ $\mathrm{Ta}=$ absolute air temperature, $\mathrm{k}$. $\mathrm{Tg}=$ final seeds temperature, $\mathrm{k}$ $\mathrm{Tgi}=$ initial seeds temperature, ${ }^{\circ} \mathrm{k} . \mathrm{t}=$ drying time, sec.

\section{RESULTS AND DISCUSSION}

\section{Bulk density of seeds:}

The experimental results of the bulk density for faba bean and lentil seeds varieties at different levels of moisture content are presented in fig. (2). As shown in the figure, the bulk density of faba bean varieties (Giza 716), (Giza 843) and (Giza 3 mohsen) were decreased from 763.6 to $706 \mathrm{~kg} \cdot \mathrm{m}^{-3}, 763.5$ to $696.4 \mathrm{~kg} \cdot \mathrm{m}^{-3}$ and 775.9 to $0.727 .4 \mathrm{~kg} \cdot \mathrm{m}^{-3}$ with the increasing of moisture content from 11.67 to 23.52 , 11.73 to 24.17 and 11.72 to $23.9 \%$ (w. b.), respectively. Meanwhile, the bulk density of lentil varieties (Sina 1, Giza 9, Giza 370) were decreased from 882.6 to $790.3,911.6$ to 799.9 and 897.8 to $785.9 \mathrm{~kg} . \mathrm{m}^{-3}$, with the increasing of moisture content from 10.44 to 24.72 , 10.63 to 24.59 and 10.54 to $24.6 \%$ (w. b.), respectively. The decrease in bulk density for the studied varieties may be due the increase in mass resulting from the increasing in moisture of seeds in a rate lower than the accompanying volumetric expansion of the seeds bulk. Similar results were obtained by Pradhan et al., (2008) for corn. A simple regression analysis was processed to assess the relationship existing between bulk density and seeds moisture content. The following regression equations was obtained:

$$
\mathbf{B}_{\mathbf{d}}=\mathbf{a} \mathbf{e}^{-\mathbf{b x}}
$$

Where: $B_{d}=$ Bulk density, $\left(\mathrm{kg} \mathrm{m}^{-3}\right)$, and a and $b=$ constants.

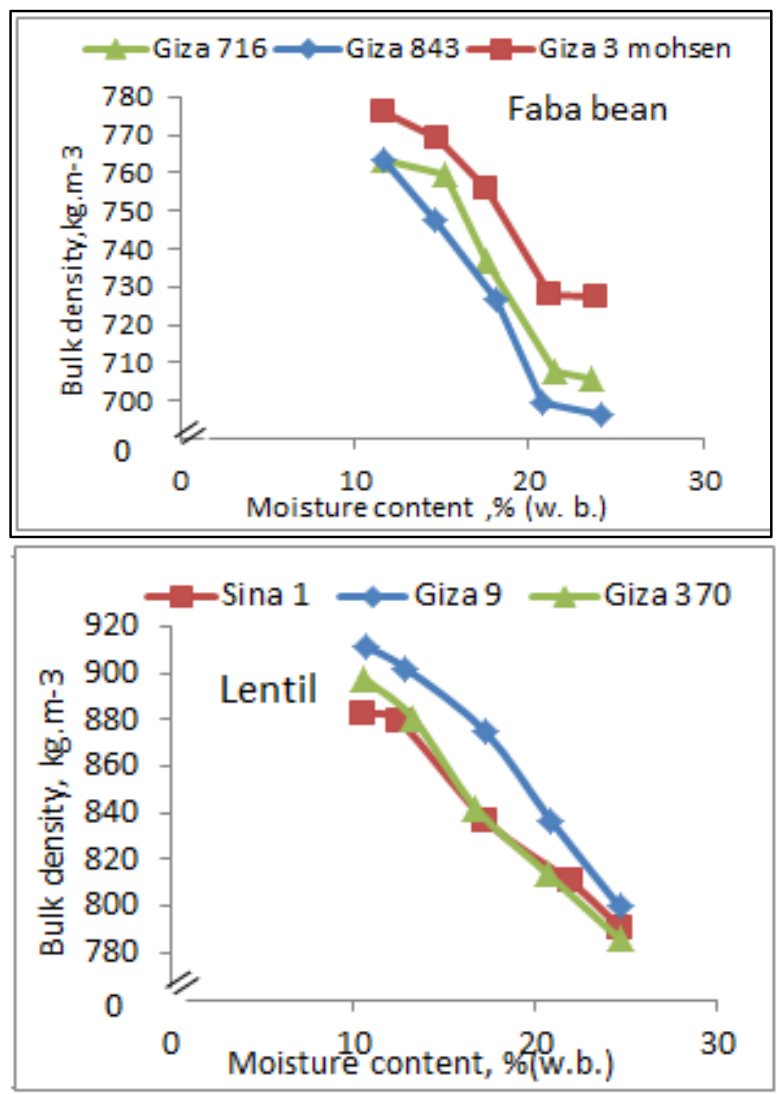

Fig. 2. Effect of moisture content on bulk density of faba bean and lentil seeds varieties.

\section{Specific Heat:}

The specific heat of faba bean and lentil seeds increased linearly with the increase of moisture content and decreased with the increase of temperature. These results are similar to the results reported by staple, (Arku, et al., 2012). 
For faba bean seeds varieties (Giza 716, Giza 843 and Giza 3 mohsen) at seeds temperature of $40^{\circ} \mathrm{C}$, the specific heat increased from (3.1218 to $3.5088 \mathrm{~kJ} \mathrm{~kg}^{-1}{ }^{\circ} \mathrm{C}^{-1}$ ),

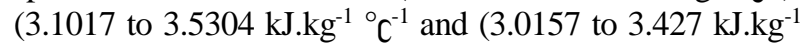
$\left.{ }^{\circ} \mathrm{C}^{-1}\right)$ as the moisture content increased from 11.67 to 23.52 , 11.73 to 24.17 and 11.72 to $23.90 \%$ (w. b.), respectively. While, the corresponding values at seeds temperature of $80^{\circ} \mathrm{C}$ were increased from $\left(2.5619\right.$ to $\left.2.7631 \mathrm{~kJ}^{\circ} \mathrm{kg}^{-1}{ }^{\circ} \mathrm{C}^{-1}\right)$, (2.515 to $2.8052 \mathrm{~kJ} \mathrm{~kg}^{-1}{ }^{\circ} \mathrm{C}^{-1}$ ), and (2.547 to $2.7947 \mathrm{~kJ} \mathrm{~kg}^{-1}$ $\left.{ }^{\circ} \mathrm{C}^{-1}\right)$, respectively. The variation of specific heat of faba bean seeds varieties with moisture content at different temperature levels is shown in Fig. (3).

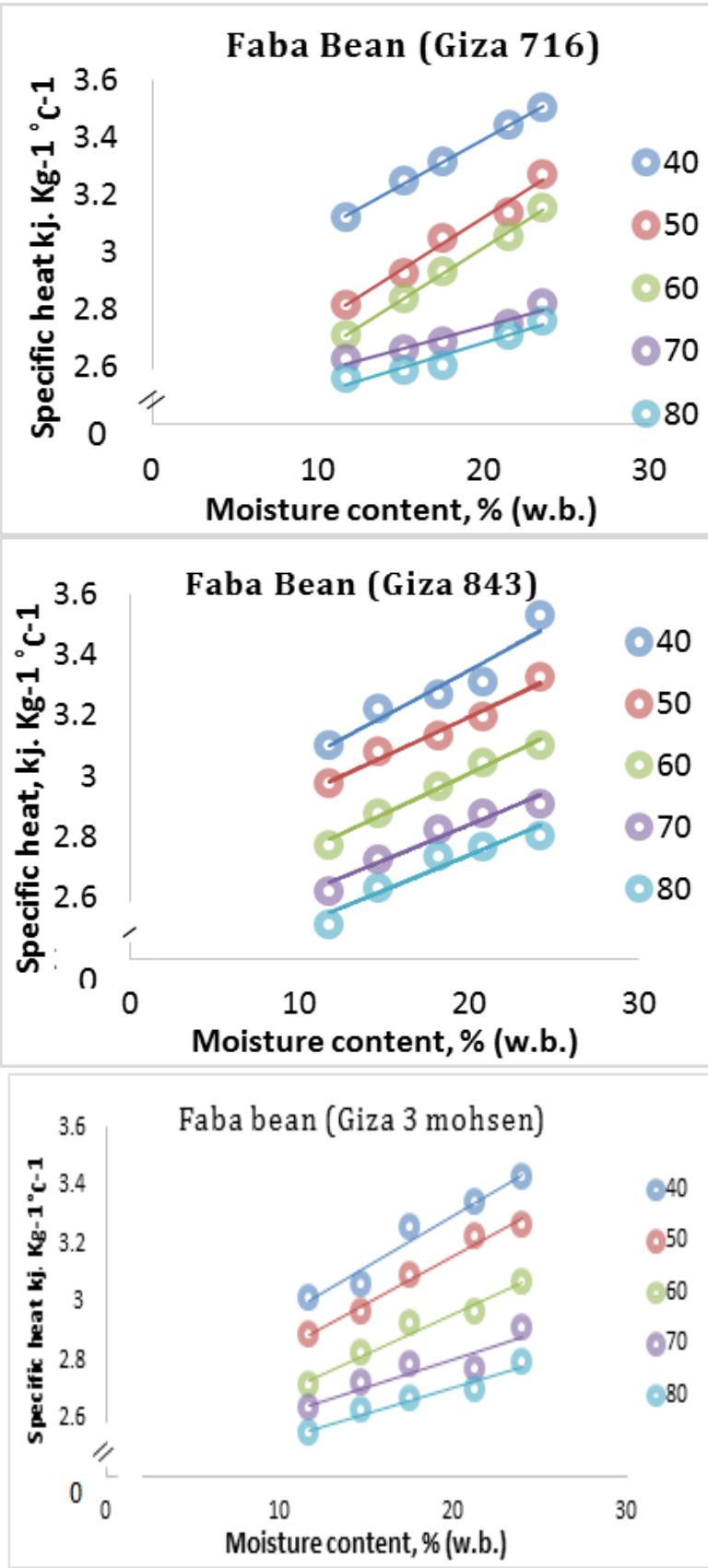

Fig. 3. Effect moisture content on specific heat of faba bean seeds varieties at different temperature levels.

The specific heat of faba bean seeds was related to seeds moisture content and temperature by the following multiple regression equations:
For variety (Giza 716),

Cpg = 3.4545+ 0.0278 (M.C.) $-\mathbf{0 . 0 1 6 9}(\mathrm{Tg})$

For variety (Giza 843),

$$
\left(R^{2}=0.9438, \text { S.E. }=0.0696\right)
$$

Cpg = 3.4372 + 0.02586 (M.C.) $-0.0154(\mathrm{Tg})$

$$
\left(R^{2}=0.9792, \text { S.E. }=0.0382\right)
$$

For variety (Giza 3 mohsen),

$$
\begin{gathered}
\text { Cpg = 3.1171 + 0.02661 }(\text { M.C. })-0.0143(\mathrm{Tg}) \ldots .(10) \\
\left(\mathrm{R}^{2}=09637, \text { S.E. }=\mathbf{0 . 0 4 8 3}\right)
\end{gathered}
$$

For lentil seeds varieties (Sina 1, Giza 9, Giza 370) at seeds temperature of $40^{\circ} \mathrm{C}$, the specific heat increased from

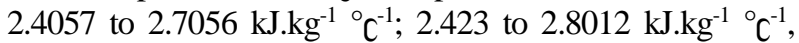
and 2.3569 to $2.7193 \mathrm{~kJ} \mathrm{~kg}^{-1}{ }^{\circ} \mathrm{C}^{-1}$ as the moisture content increased from 10.44 to $24.72,10.63$ to 24.59 and 10.54 to $24.6 \%$ (w. b.), respectively. While, the corresponding values at seeds temperature of $80^{\circ} \mathrm{C}$ were increased from 1.9564 to

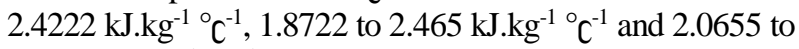
$2.3615 \mathrm{~kJ} \cdot \mathrm{kg}^{-1}{ }^{\circ} \mathrm{C}^{-1}$, respectively. The variation of specific heat of lentil varieties seeds with moisture content at different temperature levels is shown in Fig. (4).
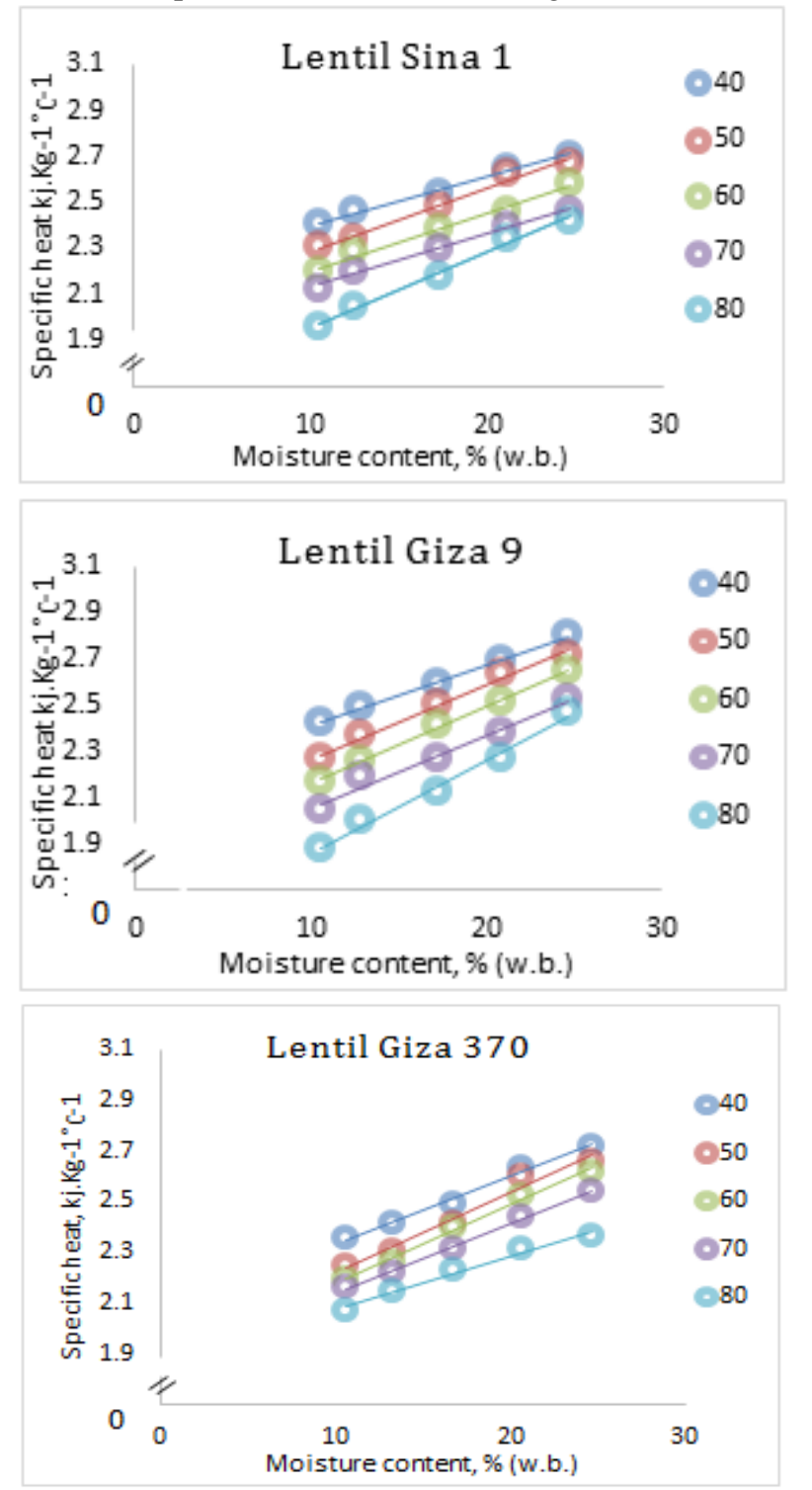

Fig. 4. Effect moisture content on specific heat of lentil varieties seeds at different temperature levels. 
Multiple regression analysis relating the specific heat of lentil seeds with the moisture content and temperature were fitted to the experimental data. The obtained relationships could be represented as follow:

For variety (Sina1),

$$
\mathrm{Cpg}=2.4838+0.02592(\mathrm{M} . \mathrm{C} .)-0.00914(\mathrm{Tg})
$$

For variety (Giza 9),

$$
\left(R^{2}=0.9799, \text { S.E. }=0.0287\right)
$$

Cpg = 2.4865+ 0.0331 (M.C,) - 0.0111(Tg)

For variety (Giza370),

$$
\left(R^{2}=0.9829, \text { S.E. }=0.0326\right)
$$

$$
\begin{gathered}
\text { Cpg }=2.3356+0.0277(\text { M.C. })-0.0071(\mathrm{Tg}) \\
\left(\mathbf{R}^{2}=\mathbf{0 . 9 7 1 1}, \text { S.E. }=\mathbf{0 . 0 3 1 6}\right)
\end{gathered}
$$

\section{Thermal conductivity}

In general, thermal conductivity increased linearly with the increasing of moisture content for both studied crops. Variation of thermal conductivity with moisture content is depicted in Fig. (5). For faba bean seeds (Giza 716, Giza 843 and Giza 3 mohsen), the thermal conductivity increased from 0.223 to $0.3259 \mathrm{~W} \cdot \mathrm{m}^{-1}$. ${ }^{\circ} \mathrm{C}^{-1}, 0.2266$ to 0.3053 $\mathrm{W} . \mathrm{m}^{-1} .{ }^{\circ} \mathrm{C}^{-1}$ and 0.2576 to $0.3390 \mathrm{~W} \cdot \mathrm{m}^{-1} .{ }^{\circ} \mathrm{C}^{-1}$, respectively as the moisture content increased from 11.67 to $24.17,11.73$ to 24.17 and 11.72 to $23.9 \%$. (w. b.). However, for lentil seeds (Sina 1, Giza 9, Giza 370), the thermal conductivity increased from 0.2356 to $0.3198 \mathrm{~W} \cdot \mathrm{m}^{-1} .{ }^{\circ} \mathrm{C}, 0.2291$ to 0.3259 $\mathrm{W} \cdot \mathrm{m}^{-1} .{ }^{\circ} \mathrm{C}$ and 0.2387 to $0.3328 \mathrm{~W} \cdot \mathrm{m}^{-1}$. ${ }^{\circ} \mathrm{C}$, respectively with the increasing of moisture content from 10.44 to 24.72 ; 10.63 to 24.59 and 10.54 to $24.6 \%$ (w. b.) and temperature from 40 to $80{ }^{\circ} \mathrm{C}$, respectively.

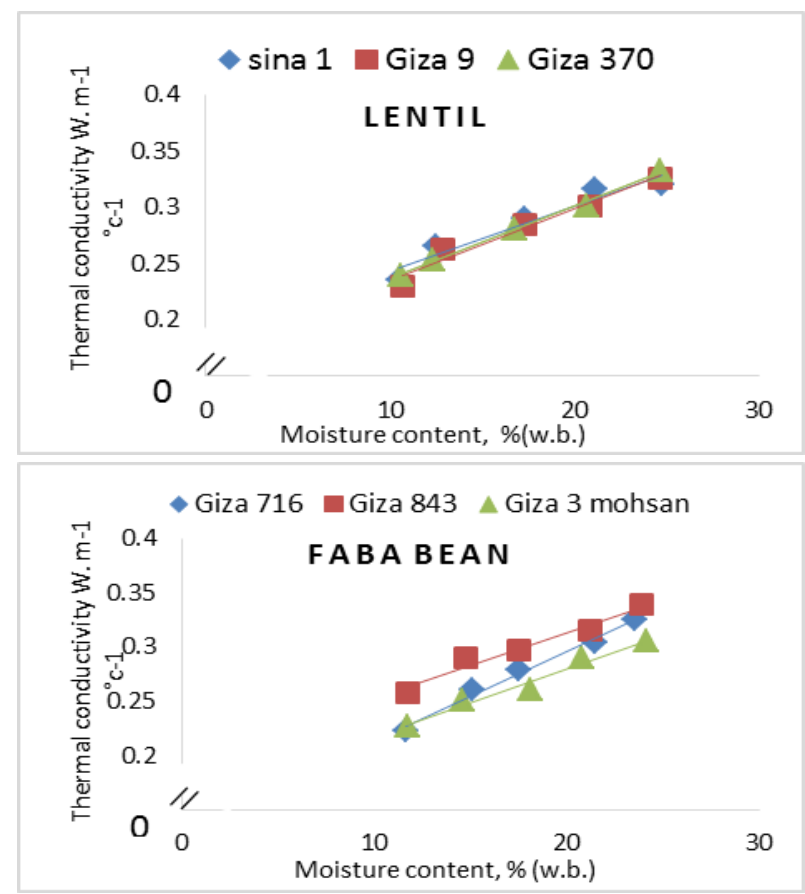

Fig. 5. Thermal conductivity of faba bean and faba bean seeds varieties as a function of moisture content.

The obtained equation relating thermal conductivity of faba bean seeds with moisture content could be presented as follows:

$$
\mathrm{K}=\mathbf{b}+\mathbf{c}(\mathbf{M . C} \text {. })
$$

Where:

$\mathrm{K}=$ Thermal conductivity, $\left(\mathrm{W} \cdot \mathrm{m}^{-1} \cdot{ }^{\circ} \mathrm{c}.\right)$, and $\mathrm{b}$ and $\mathrm{c}=$ constants.

\section{Thermal diffusivity}

Thermal diffusivity of seeds varieties was increased with the increasing of moisture content and temperature.
Also, the increasing of thermal diffusivity with moisture content and temperature exhibited positive linear relationships. Thermal diffusivity of faba bean seeds (Giza 716), (Giza 843) and (Giza 3 mohsen) increased from 0.935 $\times 10^{-4}$ to $1.35 \times 10^{-4} \mathrm{~m}^{2}$. $\mathrm{S}^{-1} ; 0.957 \times 10^{-4}$ to $1.24 \times 10^{-4} \mathrm{~m}^{2}$. $\mathrm{S}^{-1}$ and $1.1 \times 10^{-4}$ to $1.36 \times 10^{-4} \mathrm{~m}^{2} . \mathrm{S}^{-1}$ with the increasing of moisture content from 11.67 to $23.52 ; 11.73$ to 24.17 and 11.72 to $23.9 \%$ (w. b.) at seeds temperature of $40^{\circ} \mathrm{C}$, respectively. While, the corresponding values at seeds temperature of $80^{\circ} \mathrm{C}$ were increased from $1.14 \times 10^{-4}$ to 1.67 $\times 10^{-4} \mathrm{~m}^{2} . \mathrm{S}^{-1} ; 1.18 \times 10^{-4}$ to $1.56 \times 10^{-4} \mathrm{~m}^{2} . \mathrm{S}^{-1}$ and $1.3 \times 10^{-4}$ to $1.67 \times 10^{-4} \mathrm{~m}^{2} . \mathrm{S}^{-1}$, respectively as presented in Fig. (6).
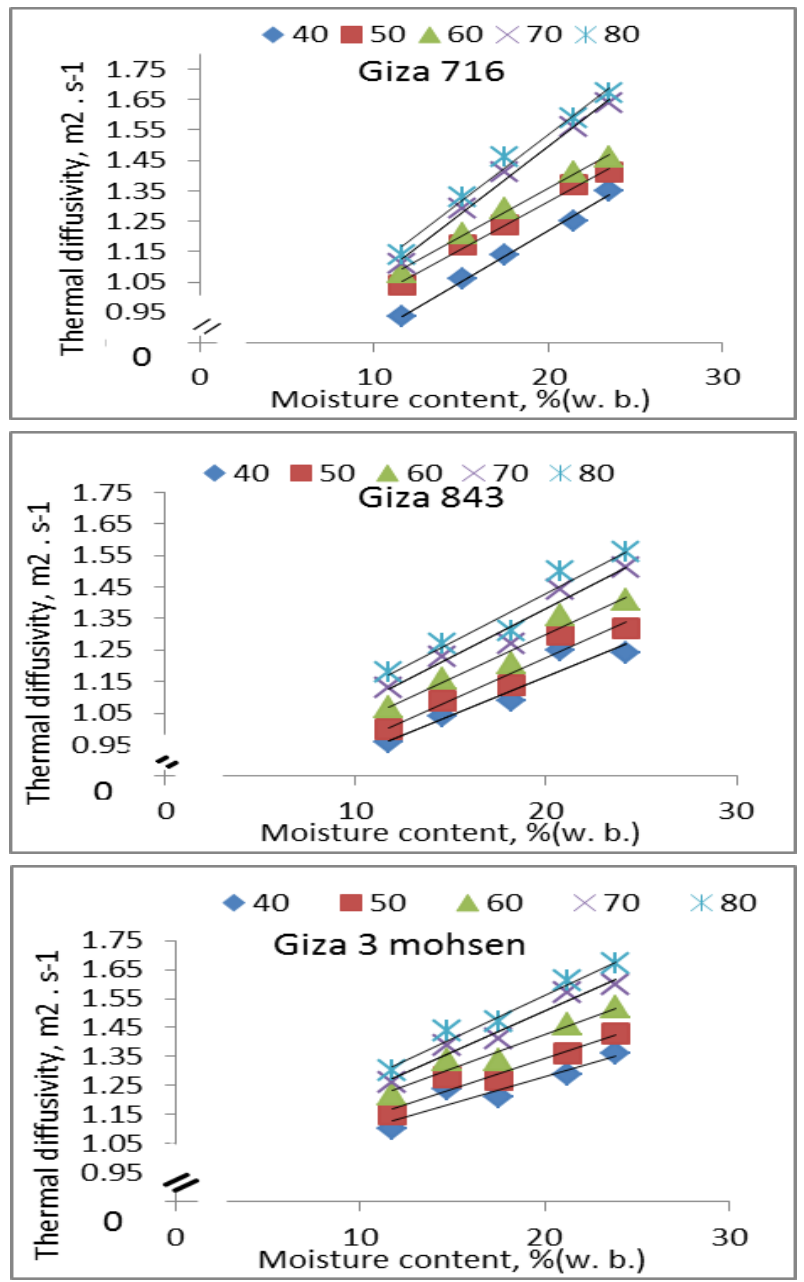

Fig. 6. Effect of moisture content on thermal diffusivity of faba bean seeds varieties at different temperature levels.

Multiple regression analysis relating the thermal diffusivity of faba bean seeds with moisture content (M.C.) and seeds temperature $(\mathrm{Tg})$ were fitted to the experimental data and the following equations were obtained:

For variety (Giza 716),

$\alpha=1.9998 \times 10^{-5}+3.7039 \times 10^{-6}($ M.C. $)+0.738 \times 10^{-5}(\mathrm{Tg}) \ldots(15)$ $\left(\mathbf{R}^{2}=0.9708\right.$, S.E. $\left.=3.5010 \times 10^{-6}\right)$.

For variety (Giza 843), $\alpha=3.45 \times 10^{-5}+2.85 \times 10^{-6}$ (M.C. $)+6.44 \times 10^{-7}(\mathrm{Tg})$

$\left(\mathbf{R}^{2}=0.9550\right.$, S.E. $\left.=3.59 \times 10^{-6}\right)$.

For variety Giza (3 mohsen),

$\alpha=5.49 \times 10^{-5}+2.39 \times 10^{-6}$ (M.C. $)+6.6 \times 10^{-7}(\mathrm{Tg}) \ldots(17)$

$\left(\mathbf{R}^{2}=0.9524\right.$, S.E. $\left.=3.34 \times 10^{-6}\right)$.

Where: $\alpha$ is the thermal diffusivity, $\left(\mathrm{m}^{2} \cdot \mathrm{s}^{-1}\right)$. 
For lentil seeds (Sina 1), (Giza 9) and (Giza 370) at seeds temperature of $40^{\circ} \mathrm{C}$, thermal diffusivity increased linearly from $1.11 \times 10^{-4}$ to $1.5 \times 10^{-4} \mathrm{~m}^{2} . \mathrm{s}^{-1} ; 1.04 \times 10^{-4}$ to $1.45 \times 10^{-4} \mathrm{~m}^{2}$. $\mathrm{s}^{-1}$ and $1.13 \times 10^{-4}$ to $1.56 \times 10^{-4} \mathrm{~m}^{2} . \mathrm{s}^{-1}$ with the increasing of moisture content from 10.44 to $24.72 ; 10.63$ to 24.59 and 10.54 to $24.6 \%$ (w. b.), respectively. While, the corresponding values at seeds temperature of $80^{\circ} \mathrm{C}$ were increased from $1.36 \times 10^{-4}$ to $1.67 \times 10^{-4} \mathrm{~m}^{2} . \mathrm{s}^{-1} ; 1.32 \times 10^{-4}$ to $1.65 \times 10^{-4} \mathrm{~m}^{2} . \mathrm{s}^{-1}$ and $1.29 \times 10^{-4}$ to $1.79 \times 10^{-4} \mathrm{~m}^{2} . \mathrm{s}^{-1}$, respectively as presented in Fig. (6).

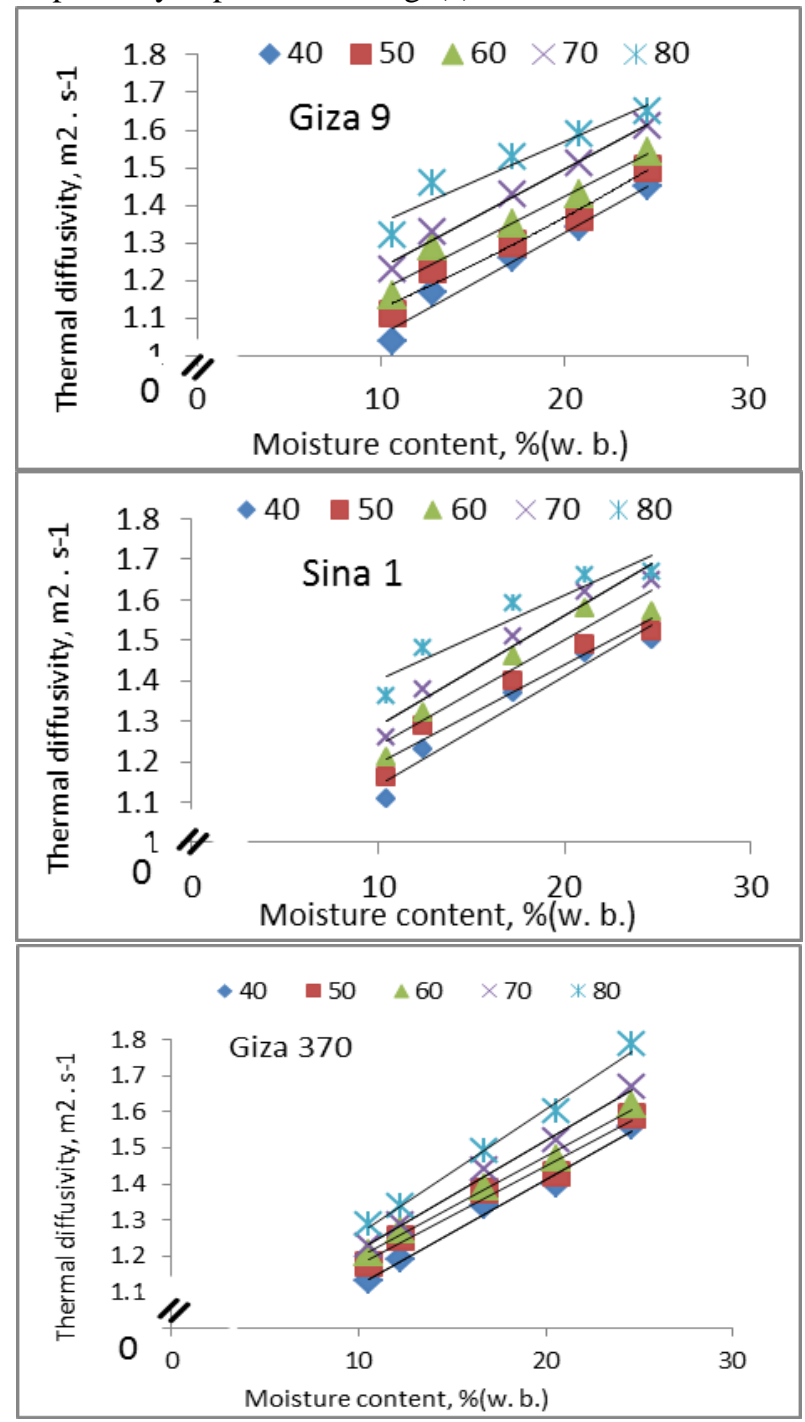

Fig. 7. Effect of moisture content on thermal diffusivity of lentil seeds varieties at different temperature levels.

Multiple regression models relating the thermal diffusivity of lentil seeds with moisture content (M.C.) and seeds temperature $(\mathrm{Tg})$ were fitted to the experimental data and the following equations were obtained:

For variety (Sina 1),

$$
\begin{gathered}
\alpha=6.76 \times 10^{-5}+2.51 \times 10^{-6}(\text { M.C. })+5.44 \times 10^{-7}(\mathrm{Tg}) \\
\left(\mathrm{R}^{2}=0.9409, \text { S.E. }=4.1 \times 10^{-6}\right)
\end{gathered}
$$

For variety (Giza 9),

$$
\begin{aligned}
& \alpha=5.57 \times 10^{-5}+2.49 \times 10^{-6}(\text { M.C. })+6.36 \times 10^{-7}(\mathrm{Tg}) . \\
& \left(\mathbf{R}^{2}=0.9679 \text {, S.E. }=3.02 \times 10^{-6}\right) \text {. } \\
& \alpha=6.44 \times 10^{-5}+2.99 \times 10^{-6}(\text { M.C. })+4.2 \times 10^{-7}(\mathrm{Tg}) \ldots(20) \\
& \left(R^{2}=0.9789, \text { S.E. }=2.6 \times 10^{-6}\right) \text {. }
\end{aligned}
$$

\section{Volumetric heat transfer coefficient}

The volumetric heat transfer coefficient was increased as the mass air flow rate and air temperature increased. The measured values of the volumetric heat transfer coefficient of faba bean seeds varieties (Giza 716, Giza 843 and Giza 3 mohsen) were increased from 8810.33 to $12199 \mathrm{~W} / \mathrm{m}^{3}$. ${ }^{\circ} \mathrm{K}, 9699.48$ to $13372.8 \mathrm{~W} / \mathrm{m}^{3}$. ${ }^{\circ} \mathrm{K}$, and 8300.02 to $13394 \mathrm{~W} / \mathrm{m}^{3}$. ${ }^{\circ} \mathrm{K}$, respectively as the mass air flow rate increased from 0.0035 to $0.0087 \mathrm{Kg} / \mathrm{m}^{2}$. s at seeds temperature of $40{ }^{\circ} \mathrm{C}$. While, the corresponding values at seeds temperature of $80{ }^{\circ} \mathrm{C}$ were increased from 15603 to $19488.6 \mathrm{~W} / \mathrm{m}^{3}$. ${ }^{\circ} \mathrm{K}, 14238.6$ to $18312.4 \mathrm{~W} / \mathrm{m}^{3}$. ${ }^{\circ} \mathrm{K}$, and 14423.4 to $17861 \mathrm{~W} / \mathrm{m}^{3} .{ }^{\circ} \mathrm{K}$, respectively.

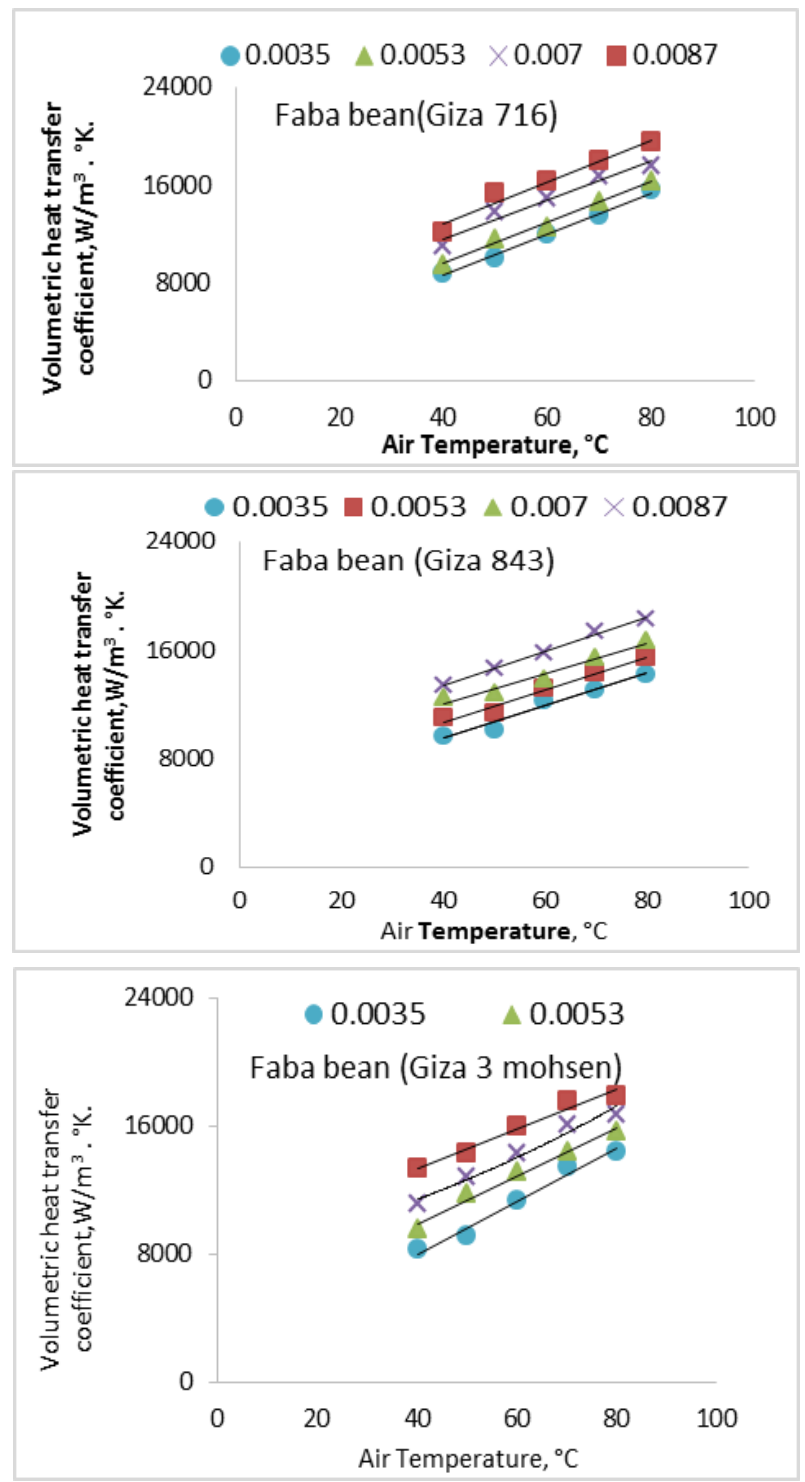

Fig. 8. Effect of air temperature on volumetric heat transfer coefficient of faba beans seeds varieties at different levels of mass air flow rates.

Meanwhile, the measured values of the volumetric heat transfer coefficient of lentil seeds varieties (Sina1, Giza 9 and Giza 370) were increased from 9114.88 to 13103.1 W/m ${ }^{3}$. ${ }^{\circ} \mathrm{K}, 7543.11$ to $11045.8 \mathrm{~W} / \mathrm{m}^{3}$. ${ }^{\circ} \mathrm{K}$, and 9778.11 to $15781.2 \mathrm{~W} / \mathrm{m}^{3}$. ${ }^{\circ} \mathrm{K}$, respectively as the mass air flow rate increased from 0.0035 to $0.0087 \mathrm{Kg} / \mathrm{m}^{2}$. s at seeds temperature of $40{ }^{\circ} \mathrm{C}$. The corresponding values at seeds temperature of $80{ }^{\circ} \mathrm{C}$ were increased from 13204.9 to 
$16152.8 \mathrm{~W} / \mathrm{m}^{3} .{ }^{\circ} \mathrm{K}, 12624.4$ to $17954.9 \mathrm{~W} / \mathrm{m}^{3}$. ${ }^{\circ} \mathrm{K}$, and 14085.9 to $18571.6 \mathrm{~W} / \mathrm{m}^{3}$. ${ }^{\circ} \mathrm{K}$, respectively.

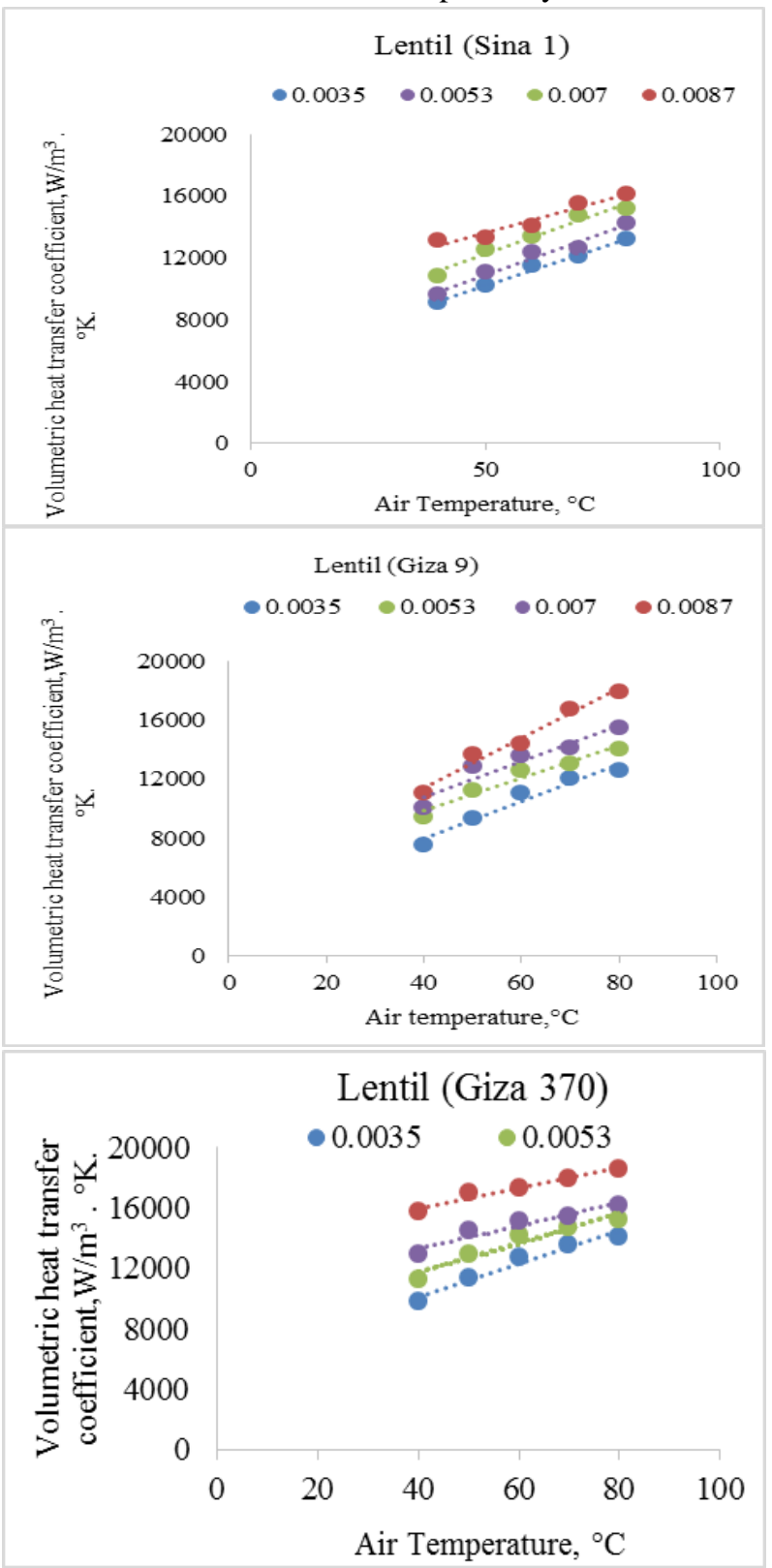

Fig. 9. Effect of air temperature on volumetric heat transfer coefficient of lentil seeds varieties at different levels of mass air flow rates.

\section{CONCLUSION}

1. The specific heat of faba bean and lentil seeds increased linearly with the increase of moisture content and decreased with the increase of temperature. Specific

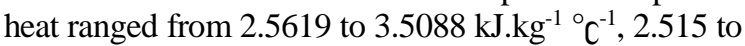
$3.5304 \mathrm{~kJ} \cdot \mathrm{kg}^{-1}{ }^{\circ} \mathrm{C}^{-1}$ and 2.547 to $3.427 \mathrm{~kJ} \mathrm{~kg}^{-1}{ }^{\circ} \mathrm{C}^{-1}$, respectively for faba beans varieties (Giza 716, Giza 843 and Giza 3 mohsen). While, it was ranged from 1.9564 to $2.7056 \mathrm{~kJ} \mathrm{~kg}^{-1}{ }^{\circ} \mathrm{C}^{-1}, 1.8722$ to $2.8012 \mathrm{~kJ} \mathrm{~kg}^{-1}$ ${ }^{\circ} \mathrm{C}^{-1}$ and 2.0655 to $2.7193 \mathrm{~kJ} \mathrm{~kg}^{-1}{ }^{\circ} \mathrm{C}^{-1}$ for lentil varieties (Sina 1), (Giza 9) and (Giza 370), respectively.

2. Thermal conductivity increased linearly with the increasing of moisture content for both studied crops. Thermal conductivity increased from 0.223 to 0.3259 W. $\mathrm{m}^{-1} .{ }^{\circ} \mathrm{c}^{-1}, 0.2266$ to $0.3053 \mathrm{~W} \cdot \mathrm{m}^{-1} \cdot{ }^{\circ} \mathrm{c}^{-1}$ and 0.2576 to
$0.3390 \mathrm{~W} \cdot \mathrm{m}^{-1} .{ }^{\circ} \mathrm{C}^{-1}$, respectively for faba bean seeds varieties (Giza 716, Giza 843 and Giza 3 mohsen). While, it was increased from 0.2356 to $0.3198 \mathrm{~W} . \mathrm{m}^{-1}$. ${ }^{\circ} \mathrm{C}, 0.2291$ to $0.3259 \mathrm{~W} \cdot \mathrm{m}^{-1}$. ${ }^{\circ} \mathrm{C}$ and 0.2387 to 0.3328 W. $\mathrm{m}^{-1}$. ${ }^{\circ} \mathrm{C}$, for lentil seeds varieties (Sina 1, Giza 9, Giza 370), respectively.

3. Thermal diffusivity of seeds varieties was increased with the increasing of moisture content and temperature. Also, the increasing of thermal diffusivity with moisture content and temperature exhibited positive linear relationships. Thermal diffusivity of faba bean seeds varieties (Giza 716, Giza 843 and Giza 3 mohsen), ranged from $0.935 \times 10^{-4}$ to $1.67 \times 10^{-4} \mathrm{~m}^{2}$. $\mathrm{S}^{-1}$; $0.957 \times 10^{-4}$ to $1.56 \times 10^{-4} \mathrm{~m}^{2}$. S $\mathrm{S}^{-1}$ and $1.1 \times 10^{-4}$ to $1.67 \times 10^{-4} \mathrm{~m}^{2} . \mathrm{S}^{-1}$, respectively at seeds temperature 40 to $80{ }^{\circ} \mathrm{C}$. While, it was ranged from $1.11 \times 10^{-4}$ to 1.67 $\times 10^{-4} \mathrm{~m}^{2} . \mathrm{S}^{-1} ; 1.04 \times 10^{-4}$ to $1.65 \times 10^{-4} \mathrm{~m}^{2} . \mathrm{S}^{-1}$ and 1.13 $\times 10^{-4}$ to $1.79 \times 10^{-4} \mathrm{~m}^{2}$. $\mathrm{S}^{-1}$ for lentil seeds varieties (Sina 1 , Giza 9 and Giza 370), respectively.

4. The volumetric heat transfer coefficient was increased as the mass air flow rate and air temperature increased. The volumetric heat transfer coefficient of faba bean seeds varieties (Giza 716, Giza 843 and Giza 3 mohsen) were ranged from 8810.33 to $19488.6 \mathrm{~W} / \mathrm{m}^{3}$. ${ }^{\circ} \mathrm{K} ; 9699.48$ to $18312.4 \mathrm{~W} / \mathrm{m}^{3}$. ${ }^{\circ} \mathrm{K}$ and 8300.02 to $17861 \mathrm{~W} / \mathrm{m}^{3} .{ }^{\circ} \mathrm{K}$, respectively. While, it was ranged from 9114.88 to $16152.8 \mathrm{~W} / \mathrm{m}^{3}$. ${ }^{\circ} \mathrm{K}, 7543.11$ to $17954.9 \mathrm{~W} / \mathrm{m}^{3}$. ${ }^{\circ} \mathrm{K}$, and 9778.11 to $18571.6 \mathrm{~W} / \mathrm{m}^{3} .{ }^{\circ} \mathrm{K}$, for lentil seeds varieties (Sina 1, Giza 9 and Giza 370), respectively.

\section{REFERENCES}

Abdellatif, K. F.; A. E., El Sayed and M. Z., Asmaa , (2012).Drought Stress Tolerance of Faba Bean as Studied by Morphological Traits and Seed Storage Protein Pattern. Journal of Plant Studies; Vol. 1, No. 2.

Arku, A.Y.; N.A. Aviara and S.C. Ahamefula, (2012). Specific heat of selected legumes and cereal grains grown in north eastern Nigeria. Arid Zone Journal of Engineering, Technology and Environment. Vol. $8,105-114$

ASAE, (1987). American society of agricultural engineers. Asae standard s352.1, st. Joseph, mi.

ASAE, (2000c). Moisture measurement - Unground grains and seeds. St. Joseph, Mich.: ASAE.

Aviara, N.A.; M.A., Haque and L.A.O., Ogunjimi, (2008). Thermal properties of guna seed. Int. Agrophysics, 22, 291-297.

Azadbakht, M.; H. K. Mohamad; G. Barat and M. Saeid, (2013).

Balasubramanian, D., (2001). Physical properties of raw cashew nut. Journal of Agricultural Engineering Research, 78: 291-297.

Gharibzahedi, S. M. T.; G., Mohammad and S. L., Zhaleh, (2013). Specific Heat, Thermal Conductivity and Thermal Diffusivity of Red Lentil Seed as a Function of Moisture Content. Journal of Food Processing and Preservation 38(4): 1807-1811. 
Gharibzahedi, S. M. T.; Z., Emam-Djomeh; S. H. Razavi and S. M., Jafari, (2014). Mechanical behavior of lentil seeds in relation to their physicochemical and microstructural characteristics. International Journal of Food Properties 17(3): 545-558.

Jangi, A. N.; S.A., Mortazavi; M., Tavakoli; A., Ghanbari; H., Tavakolipour and G.H., Haghayegh, (2011). Comparison of mechanical and thermal properties between two varieties of barley (Hordeum vulgare L.) grains. AJAE 2(5):132-139, ISSN: 1836-9448.

Matouk, A. M.; M. M., EL-Kholy; A. S., Hamam and T. R., Owies, (2006 a). Thermal conductivity and diffusivity as a function of moisture content of some cereal crops" Mansoura Univ., J. of Agric. Sci. Vol. 31 No (7): 451- 464.

Matouk, A. M.; M. M., EL-Kholy; S. M., Radwan and T. R., Owies, (2006 b). "Determination of Heat Transfer Coefficient for Some Varieties of Cereal Crops". Mansoura Univ., J. of Agric. Sci. Vol. 31 No (7): 433- 442.

Matouk, A. M.; M. M., EL-Kholy; T. R., Owies and S. M., Radwan, (2006 c). Effect of moisture content on specific heat of some cereal crops- Mansoura Univ. J. Agric. Sci. Vol 31 N0 (5).

Matouk, A. M.; S. M., Abd El-Latif; Y. M., El-Hadidi and A., Tharwat, (2001). "Drying of ear corn: Part I: The determination of drying parameters" Misr. J. Agric. Engng., Vol.18 (2).
Matouk, A. M.; S. M., Radwan; M. M., El-Kholy and T. R., Owies, (2004 b). Determination of grains density and porosity for some cereal crops Misr J. Agric. Eng. Vol. 21 (3): 623-641.

Mohsenin, N. N., (1980). Thermal Properties of foods and agricultural materials. pp. 83-121, Gordon and Breach Science Publishers. New York, N.Y.

Ogunjimi, L.A.O., N.A., Aviara and O.A., Aregbesola, (2002). Some engineering properties of locust bean seed. Journal of Food Engineering, 55: 95-99.

Pradhan, R.C.; S.N., Naik; N., Bhatnagar and S.K., Swain, (2008). Moisture dependent physical properties of Karanja (Pongamia pinnata) kernel. Ind. Crops Prod., 28(2): 155-161.

Tang, J.; S., Sokhansanj; S., Yannacopoulos and S.O., Kasa,(1991). Specific heat capacity of lentil seeds by differential scanning calorimetry. Trans. of the ASAE 34: 517-522.

Thermal Properties of Soybean Pod as a Function of Moisture Content and Temperature. American Journal of Food Science and Technology, Vol. 1, No. 2, 9-13.

\section{الخواص الحرارية لبعض المحاصيل البقولية

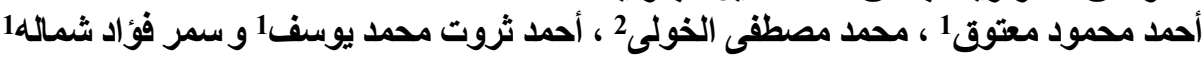

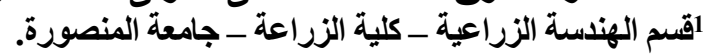 2قسم هندة التصنيع و التداول - معهد بحوث الزعة الهندسة الزراعية.}

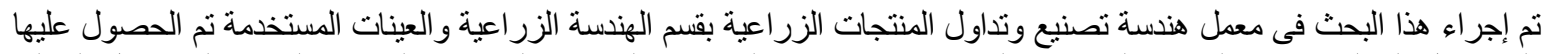

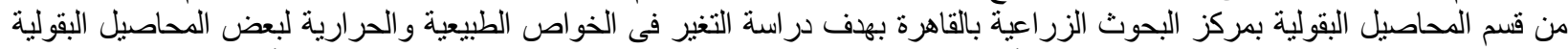

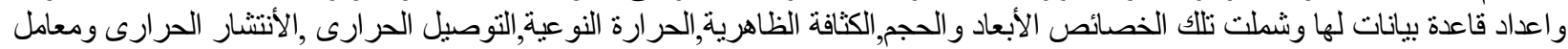

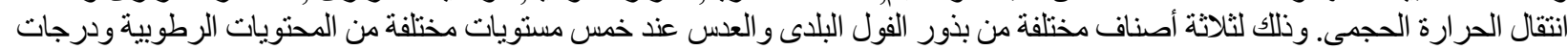

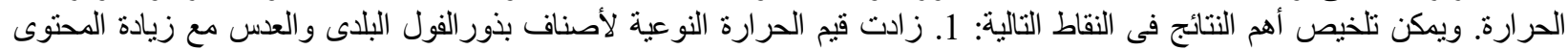

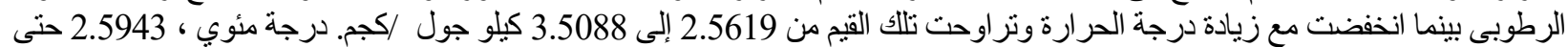

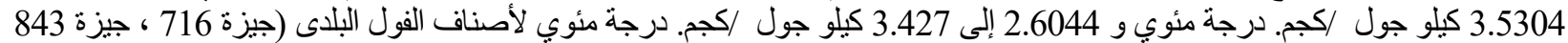

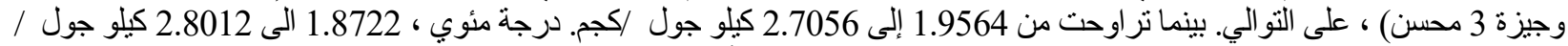

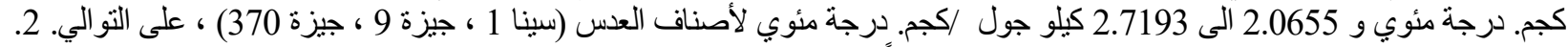

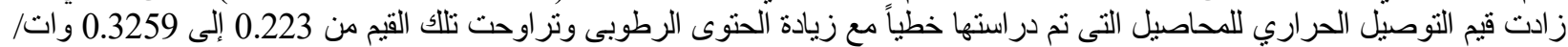

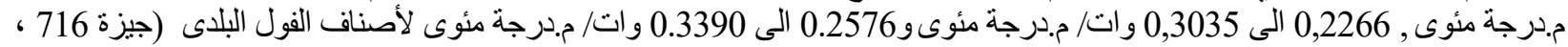

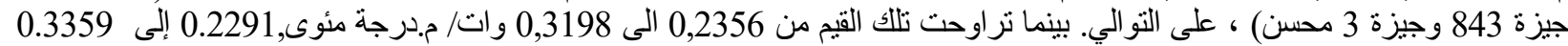

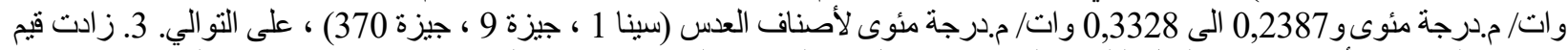

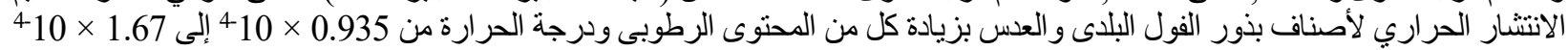

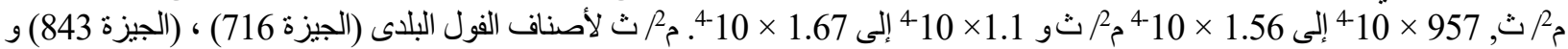

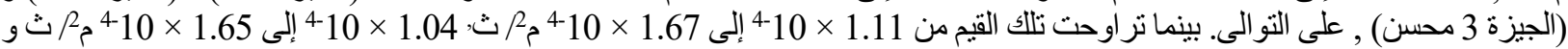

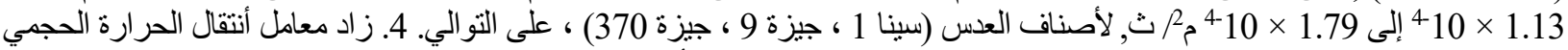

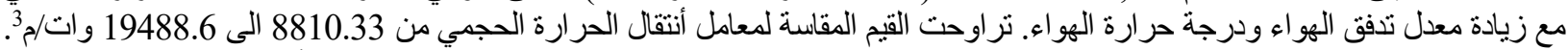

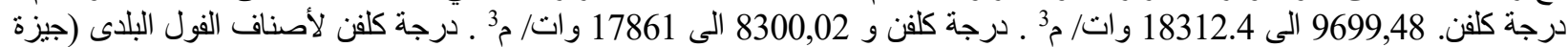

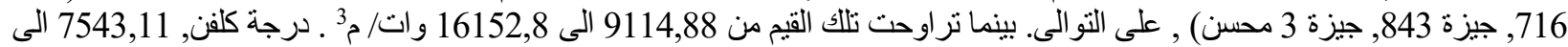

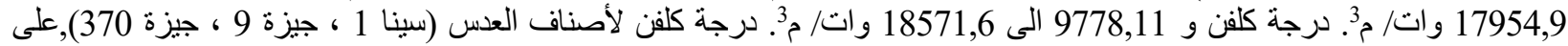

